J. Kyushu Dent. Soc. 52 ( 5 ) : 567 575, 1998.

\title{
Hepatitis Virus Infection and Hepatic Disease in Hospitalized Dental Patients
}

\author{
Yutaka Takata*, Akira Tateishi**, Hideo Kurokawa***, Megumi Fujikawa*, \\ Masanori Wakisaka*, Kiyoshi Matsumura*, Yoshito Nakamura*, \\ Jinichi Fukuda**, and Minoru Kajiyama*** \\ ${ }^{*}$ Department of Internal Medicine (Chief: Prof. Yutaka Takata) \\ ${ }^{* *}$ First Department of Oral Surgery (Chief: Prof. Jinichi Fukuda) \\ ${ }^{* * *}$ Second Department of Oral Surgery (Chief : Prof. Minoru Kajiyama) \\ Kyushu Dental College, Kitakyushu, Japan.
}

\begin{abstract}
Key words: Dental/Hepatitis B/Hepatitis C/Hepatitis virus/Oral surgery
\end{abstract}
Accepted on August 25, 1998

\section{Introduction}

Viral hepatitis is an important disease in dental practice, in light of infections from patientto-patient or patient-to-doctor, as well as bleeding tendencies during treatment ${ }^{1-3)}$. Although the transmission of hepatitis virus $\mathrm{B}(\mathrm{HBV})$ and $\mathrm{C}(\mathrm{HCV})$ is mainly via blood and blood products $^{2)}$, saliva may also be one source of infection with $\mathrm{HBV}^{4)}$ and $\mathrm{HCV}^{5,6)}$. Needle-stick injury during dental treatment may be responsible for infection, among dental personnel. In our dental hospital ${ }^{7}$, needle-stick injuries have occurred 35 times during the past 3 years, in which 8 patients were $\mathrm{HCV}$-seropositive and 1 was positive for $\mathrm{HB}$ surface (HBs) antigen. Dentists have a higher prevalence of seropositivity for HBs and HCV than controls, indicating high occupational risk for $\mathrm{HBV}^{8,9)}$ and $\mathrm{HCV}$ infection ${ }^{10,11)}$. In particular, the prevalence was high among oral surgeons ${ }^{8,9,12)}$. To protect dentists from these viruses, it is essential to have a precise knowledge of the prevalence of hepatitis virus carriers in dental patients. Recently, Shopper et al (1995) ${ }^{13)}$ have reported the prevalence of exposure to HCV in a sample of dental school outpatients, demonstrating that more than $5 \%$ were positive for anti-HCV. This rate of $\mathrm{HCV}$ seropositivity was apparently higher than in the general population.

In this study, we screened a large population of hospitalized dental patients to elucidate the prevalence of hepatitis viruses $\mathrm{B}$ and $\mathrm{C}$ carriers correlated with a clinical history of liver disease. The serum chemistries and bleeding tendencies associated with $\mathrm{HBV}$ and $\mathrm{HCV}$ also were evaluated.

\section{Patients and Methods}

Subjects included 1239 consecutive dental patients who were hospitalized from January 1994 to December 1995 at the First and Second Divisions of Oral Surgery, Kyushu Dental College Hospital, Kitakyushu, Japan. It may be important that we emphasize the fact that these were 
Table 1 Clinical characteristics of study patients

\begin{tabular}{|c|c|c|c|c|c|}
\hline Sex : & $\mathrm{n}=$ & $664(53.6)$, & $\mathrm{F}$ & $\mathrm{n}=575$ & \\
\hline Age : & $41.1 \pm 0.6$ & (0 to 97 years old) & & & \\
\hline \multicolumn{6}{|c|}{ Dental diagnosis : } \\
\hline & Inflammation & $\mathrm{n}=407(32.8)$ & & Cysts & $\mathrm{n}=166(13.4)$ \\
\hline & Trauma & $\mathrm{n}=161(13.0)$ & & Cancer & $\mathrm{n}=160(12.9)$ \\
\hline & Impacted teeth & $\mathrm{n}=119(9.6)$ & & Anomaly & $\mathrm{n}=79(6.4)$ \\
\hline & Benign tumors & $\mathrm{n}=78(6.3)$ & & Sialolithiasis & $\mathrm{n}=17(1.4)$ \\
\hline & Others & $\mathrm{n}=52(4.2)$ & & & \\
\hline
\end{tabular}

HBs antigen :

Positive $\mathrm{n}=16(1.6)$

Negative $\quad \mathrm{n}=982$

$\mathrm{HCV}$ antibody:

Positive $\quad \mathrm{n}=60(6.1) \quad$ Negative $\quad \mathrm{n}=918$

History of liver disease :

Positive $\quad \mathrm{n}=97(7.8)$

Negative $\quad \mathrm{n}=1142$

in-patients receiving oral and dental care. This study was approved by the Human Investigations Committees of Kyushu Dental College. The clinical characteristics of the patients are shown in Table 1. Inflammation comprised one third of all dental diseases, followed by cysts, trauma, and cancer. The diagnosis classified as the inflammation was 179 periostitis, 122 phlegmone, 39 sinusitis, 14 osteomyelitis, 11 abscess, 10 lymphadenitis, 10 paradentitis, 7 stomatitis, 6 salivary gland inflammation, and 9 the others. Any clinical history of liver disease was asked of each patient by a physician in charge. The main medical diseases other than dental or liver disease were 132 hypertension, 61 ischemic heart disease, 57 diabetes mellitus, 42 drug allergy, 23 gastro-duodenal ulcer, 23 arrhythmia. Blood samples were taken for the measurement of blood chemistry, which included: aspartate transaminase (AST), alanine transaminase (ALT), fasting plasma glucose (FPG), red cell, white cell, and platelet counts, hematocrit, and hemoglobin. Bleeding times and coagulation times also were examined. Bleeding time was done by a small cut in ear lobe. Serum HBs antigen and $\mathrm{HCV}$ antibody (using a second generation serologic enzyme immunoassay) were determined. This enzyme immunoassay for $\mathrm{HCV}$ antibody detects human antibody to recombinant $\mathrm{HCV}$ antigen proteins $\mathrm{c} 200, \mathrm{c} 22-3, \mathrm{HC}-34$, and $\mathrm{HC}-31$. All data are presented as the mean \pm SEM Differences were examined with the unpaired Student's $T$ test where appropriate, and categorical variables were compared using the chi square test. Results were considered to be significant when the $\mathrm{p}$ value was less than 0.05 .

\section{Results}

Sixteen of 998 inpatients, for whom a blood sample was available, had HBs antigen in their 


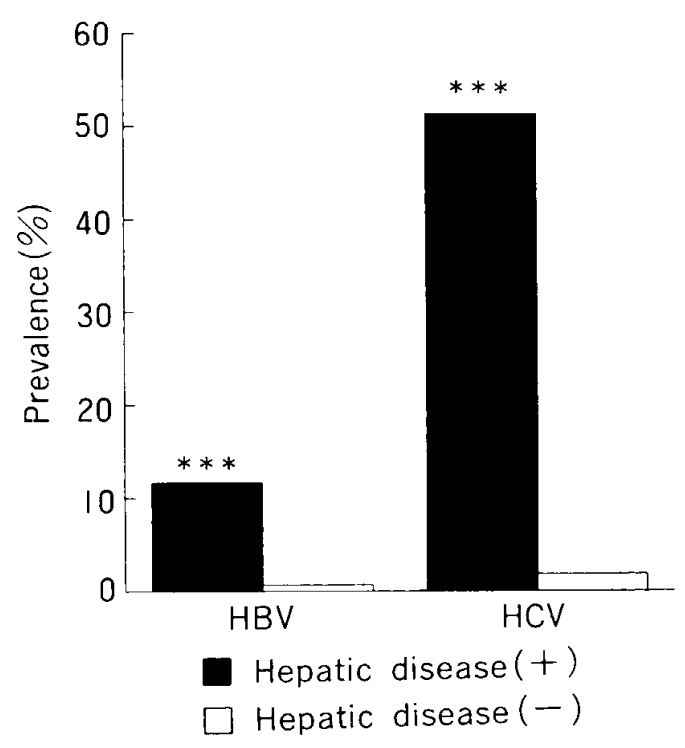

Fig. 1 Prevalence of the frequency of Hepatitis $\mathrm{B}$ surface antigen ( $\mathrm{HBV}$ ) and $\mathrm{HCV}$ antibody (HCV) in patients with or without a history of hepatic disease.

$* * *: \mathrm{p}<0.001$ in comparison with subjects with and without hepatic disease

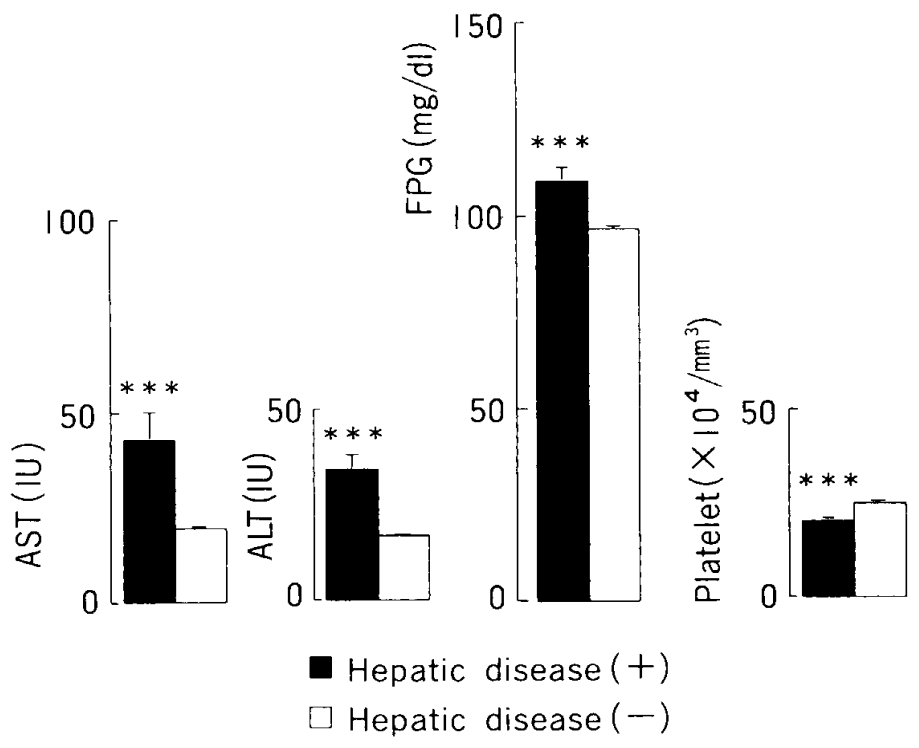

Fig. 2 Serum aspartate transaminase (AST; IU), alanine transaminase (ALT; IU), fasting plasma glucose (FPG; mg/dl), and platelet counts (Platelet; $x 10^{4} / \mathrm{mm}^{3}$ ) in patients with or without a history of hepatic disease.

$* * *: \mathrm{p}<0.001$ in comparison with subjects with and without hepatic disease

serum (1.6\%), while 60 of 978 were $\mathrm{HCV}$ seropositive $(6.1 \%)$ (Table 1). The occurrence of a positive reaction was higher for $\mathrm{HCV}$ antibody than $\mathrm{HBs}$ antigen $(\mathbf{p}<0.001)$. Ninety-seven patients had a present or past history of liver disease, and the other 1142 had no history of liver disease (Table 1). The prevalence of HBs antigen was much higher in the former than in the latter $(11.6 \%$ vs. $0.66 \% ; \mathrm{p}<0.001$ ) (Fig. 1). Similarly, dental patients with a history of hepatic disease were positive more frequently for $\mathrm{HCV}$ antibody than those without $(51.2 \%$ vs. $1.79 \%, \mathrm{p}<0.001)$.

Dental patients with a history of hepatic disease had increased serum levels of AST ( $<<$ $0.001)$, ALT $(p<0.001)$, and FPG $(p<0.001)$ as compared to those without hepatic disease (Fig. 2). Blood platelet counts in subjects with hepatic disease were significantly lower than in those without $(\mathrm{p}<0.001)$, but bleeding tendencies examined by both bleeding time and coagulation time, did not differ between the two groups. The red blood cell counts, white blood cell counts, hemoglobins, and hematocrits were similar in the groups. The subjects with liver disease were older than those without $(54.4 \pm 1.5$ vs. $40.1 \pm 0.6, p<0.001)$.

Figure 3 shows a comparison of serum chemistries, platelet counts and ages between subjects with and without hepatitis virus $\mathrm{B}$ or $\mathrm{C}$ infection. $\mathrm{HB}$ virus (HBV) carriers had slightly decreased blood platelet cell counts than non-carriers, but FPG, AST, and ALT levels did not differ between the groups. On the other hand, among HCV-antibody positive reactors, FPG, AST, and ALT were significantly higher and platelet counts were lower than 

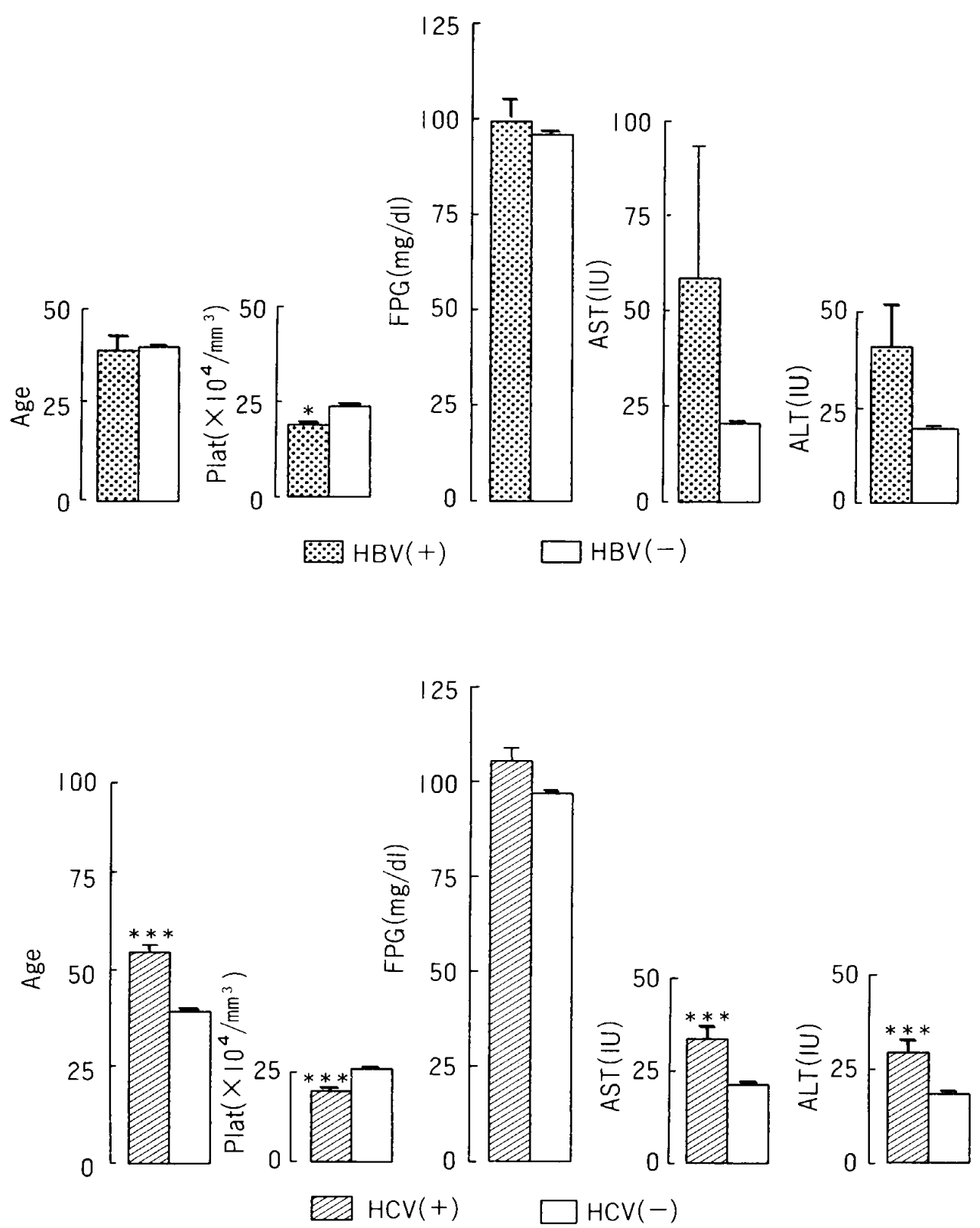

Fig. 3 Age, platelet counts (Plat), FPG, AST, ALT with or without serum HBs antigen (Upper panel) and with or without serum HCV antibody (Lower panel).

$*: \mathrm{p}<0.05, * * *: \mathrm{p}<0.001$ in comparison with subjects with and without $\mathrm{HBs}$ antigen (upper) or $\mathrm{HCV}$ antibody (lower)

in the HCV-negative group. HCV-positive group was older than HCV-negative group, while age did not differ between the subjects of HBs antigen-positive and -negative.

Further analysis of the occurrence of serum HBs antigen, HCV antibody, and liver disease history by age-stratification (Fig. 4) shows that the highest prevalence of HCV and a history of liver disease was detected in 60 to 69 year old patients, but HBs antigen was most frequently noted in 30 to 39 year old subjects. The prevalence in 10-year age-groups of HBs 
antigen ranged from 0 to $3.5 \%$, and that of $\mathrm{HCV}$ antibody from 0 to $10.3 \%$. The occurrence of HBs antigen was similar in patients with different dental diseases, such as inflammation (1.7\%), cysts $(2.0 \%)$, trauma $(0.7 \%)$, cancer $(0 \%)$, impacted teeth $(1.9 \%)$, anomalies $(0 \%)$, and benign tumors (2.8\%). $\mathrm{HCV}-$ antibody also was detected similarly in patients with various dental diseases (inflammation $7.7 \%$, cysts $3.4 \%$, trauma $3.7 \%$, cancer $8.0 \%$, impacted teeth $5.8 \%$, anomalies $5.6 \%$, benign tumors $5.8 \%$ ). Although the prevalence of $\mathrm{HBs}$ antigen in benign tumors, and that of $\mathrm{HCV}$-antibody in cancer seems be greater than the others, no significant differences were noted either in the case of $\mathrm{HBs}$ antigen or $\mathrm{HCV}$ antibody, probably due to small number of patients for each group.

\section{Discussion}

In this large population study of dental college hospital inpatients, the prevalence of HBs antigen was $1.6 \%$, and that of $\mathrm{HCV}$ antibody $6.1 \%$, which are apparently higher than in the general populations of recent Japan $(0.41 \%$ for HBs antigen and $1.39 \%$ for $\mathrm{HCV}$ antibody in 1993 ${ }^{14)}$, the United States, and Western Europe ${ }^{15)}$. There are areas such as Italy, Spain perhaps Japan and Egypt where $\mathrm{HCV}$ is endemic. Although hepatitis viruses infections might be endemic diseases in our local area, the prevalence of anti-HCV was $286(2.0 \%)$ of 14,341 subjects among the general population of Fukuoka ${ }^{16)}$, Japan where our study has been performed. Similarly, the other study showed the prevalence of anti-HCV was $3.3 \%$ in the general population in Fukuoka ${ }^{17)}$, Japan. On the other hand, the frequency of subjects with HBs antigen was $18(1.1 \%)$ of 1638 for health care personnel in Fukuoka ${ }^{18}$, Japan. Therefore, these observations with the present results further suggest that dental college hospital inpatients are infected with hepatitis viruses $\mathrm{B}$ and $\mathrm{C}$ more frequently than subjects in a general population. Since the prevalence of HBs antigen or HCV antibody was similar in patients with different dental diseases in our study, differences in dental disease do not explain the high prevalence. In a dental school outpatient $(n=500)$ population, Shopper et al .${ }^{13)}$ have reported a similar high occurrence $(5.5 \%)$ of serum HCV-antibody, similar to our observation, indicating that dental school hospital patients are infected frequently with both $\mathrm{HBV}$ and HCV. The reason why the dental patients have hepatic disease or be carriers of $\mathrm{HCV}$ or $\mathrm{HBV}$ was not answered by this study. Although social class may be related with 
hepatitis viruses infection, each patient was not asked question about his social histories, since those such as annual income, educational background, type of job, official position, birthplace should not be taken in Japan in case of usual hospitalization to protect a individual patient right.

This high prevalence of $\mathrm{HBV}$ - and $\mathrm{HCV}$-infected dental patients may lead to an increase in the occurrence of $\mathrm{HBV}$ and $\mathrm{HCV}$ infections in dental staff through accidents such as needlestick injury. Therefore, dentists should pay careful attention to avoid infection with hepatitis viruses during dental practice. Immunization against HBV may decrease the occurrence of HBV infection ${ }^{3,19)}$.

The reason for the discrepancy with the findings by Nagao et al. (1995) ${ }^{20)}$, who have demonstrated high prevalence of hepatitis $\mathrm{C}$ virus antibody and RNA in oral cancer patients, remains unknown. They analyzed 100 oral cancer patients who had been admitted from 1989 to 1993. On the other hand, we in this paper examined 160 hospitalized cancer patients admitted from 1994 to 1995 . We have 4 times more oral cancer patients annually than them. This may simply reflect differences in patients population between their hospital and ours.

A comparison of HBs-antigen with $\mathrm{HCV}$-antibody seems somewhat peculiar. However, the measurement of HCV-RNA, which indicates the carrier state for HCV, in all 998 inpatients serum is considerably hard and expensive. Therefore, instead of HCV-RNA, we measured HCV-antibody. After this study completion, serum HCV-RNA was examined only in subjects with $\mathrm{HCV}$-antibody. In patients with anti-HCV antibody, 53.2\% were positive for $\mathrm{HCV}-$ $\mathrm{RNA}^{21)}$.

Subjects with hepatic disease were reactive much more frequently to HCV-antibody and HBs-antigen than those without liver disease. The liver disease patients or hepatitis virus carriers had not only increased levels of AST and ALT, but decreased platelet counts, which might be associated with bleeding tendencies during dental procedures. In addition, FPG values were higher in these subjects, which might cause infection after dental surgery. These observations suggest that taking a history of liver disease is useful for estimating whether the patient is a hepatitis virus carrier, and dentists should treat patients with a history carefully to avoid infection. Additionally, since in these patients hemorrhagic accidents or infection might be induced by dental procedures, sufficient hemostasis and bleeding prevention, as well as high dosages of antibiotics should be used. The prevalence (7.8\%) of hepatic disease based on history in our study was similar to that from patient self-completed health questionnaires reported by Fenlon and McCartan (1991)22), who found hepatitis in $7.9 \%$ of subjects attending a primary health care dental practice. Although most hepatitis virus carriers had a history of hepatic disease, 6 of 912 and 16 of 892 subjects without a history were carriers of $\mathrm{HBV}$ and $\mathrm{HCV}$, respectively. This means that history taking cannot completely eliminate the risk that the patient is a carrier of these viruses. Careful dental technique for all patients is needed to prevent trasmission of hepatitis viruses.

In conclusion, the prevalence of $\mathrm{HBV}$ and $\mathrm{HCV}$ carriers is higher in dental college hospital inpatients than in the general population. A clinical history of liver disease is useful in 
determining whether the patient is a carrier of a hepatitis virus or impared liver function.

\section{Summary}

We determined the prevalence of hepatitis virus carriers in a large population of hospitalized dental patients. The serum chemistries and bleeding tendencies associated with hepatitis $\mathrm{B}$ virus (HBV) and hepatitis C virus (HCV) also were evaluated. Twelve hundred thirty-nine consecutive hospitalized patients in a dental ward were questioned regarding a medical history of liver disease. Blood samples were taken for blood chemistry and platelet count. Serum HBs antigen and $\mathrm{HCV}$ antibody also were measured. Sixteen of 998 inpatients had serum HBs antigen (1.6\%), while 60 of 918 were HCV seropositive (6.1\%). Ninetyseven patients had a present or past history of liver disease (7.8\%), and the other 1142 had no history of liver disease. The prevalence of both HBs antigen and HCV antibody was much higher in the former than in the latter. This group had increased serum levels of aspartate transaminase, alanine transaminase, and fasting plasma glucose. Blood platelet counts in hepatic disease subjects were decreased. We determined that in a large population of dental college hospital inpatients, the occurrence of HBs antigen was $1.6 \%$, and that of $\mathrm{HCV}$ antibody $6.1 \%$, which is greater than in the general population. In patients with a history of liver disease dentists should take care to avoid exposure to viruses.

\section{Acknowledgments}

This work was partly supported by Grant-in-Aid for Scientific Research (C) (08672323).

\section{References}

1) Winsom, C. J. and Kelly, M.: Medical/dental management of a chronic hepatitis C patient. Oral Surg. Oral Med. Oral Pathol. 75: 786-790, 1993.

2 ) Porter, S., Scully, C. and Samaranayake, L.: Viral hepatitis; Current concepts for dental practice. Oral Surg. Oral Med. Oral Pathol. 78: 682-695, 1994.

3 ) Wisnom, C. J. and Lee, R. J. : Increased seroprevalence of hepatitis B in dental personnel necessitates awareness of revised pediatric hepatitis B vaccine recommendations. J. Public Health Dent. 53: 231234, 1993.

4 ) Ben-Aryeh, H., Ur, I. and Ben-Porath, E.: The relationship between antigenaemia and excretion of hepatitis B surface antigen in human whole saliva and in gingival crevicular fluid. Arch. Oral Med. $30: 97-90,1985$.

$5)$ Roy, K. M., Bagg, J., Follett, E. A., Brewer, A. and Lowe, G. D.: Hepatitis C virus in saliva of haemophilic patients attending an oral surgery unit. Br. J. Oral Maxillofaci. Surg. 34: 162-165, 1996.

6) Liou, T. C., Chang, T. T., Young, K. C., Lin, C. Y. and Wu, H. L.: Detection of HCV RNA in saliva, urine, seminal fluid, and ascites. J. Med. Virol. 37 : 197-202, 1992.

7 ) Toyoda, K., Takata, Y., Fujikawa, M., Kuroda, T., Yao, H. and Tsuchihashi, T.: Needlestick injury among dental personnel. J. Kyushu Dent. Soc. 50: 411-414, 1996.

8 ) Smith, J. L., Maynard, J. E. and Berquist, K. R.: Comparison risk of hepatitis B among physicians and dentist. J. Infect. Dis. 133: 705-706, 1976.

9 ) Feldman, R. E. and Schiff, E. R. : Hepatitis in dental professionals. J. A. M. A. 232: 1228-1230, 1975.

10) Klein, R.S., Freeman, K., Taylor, P. E. and Stevens, C. E.: Occupational risk for hepatitis C virus 
infection among New York City dentists. Lancet 338: 1539-1542, 1991.

11) Lodi, L., Porter, S. R., Sardella, A. and Carrassi, A.: Hepatitis C and dentistry. Minerva Stomatol. 45: 253-258, 1996.

12) Thomas, D. L., Gruninger, S. E., Siew, C., Joy, E. D. and Quinn, T. C. : Occupational risk of hepatitis $\mathrm{C}$ infections among general dentists and oral surgeons in North America. Am. J. Med. 100: 41-45, 1996.

13) Shopper, T., Boozer, C., Lancaster, D., Cade, J. E. and Lundgren, G.: Presence of anti-hepatitis C virus serum markers in a dental school patients population. Oral Surg. Oral Med. Oral Pathol. 79 : 655-660, 1995.

14) Tanaka, J. and Yoshizawa, H.: Epidemiology of hepatitis virus B and C. J. Clin. Exp. Med. 171: 959964 (in Japanese), 1994

15) Ockner, R. K. : Acute viral hepatitis. In: Textbook of Medicine (ed. by Bennett, J. C. and Plum, F.). Philadelphia, PA, Saunders, 1996, 766-768.

16) Hayashi, J., Nakashima, K., Yoshimura, E., Hirata, M., Maeda, Y. and Kashiwagi, S.: Detection of HCV RNA in subjects with antibody to hepatitis C virus among the general population of Fukuoka, Japan. J. Gastroenterol. 29: 147-151, 1994.

17) Hayashi, J., Yoshimura, E., Nabeshima, A., Kishihara, Y., Ikematsu, H., Hirata, M., Maeda, Y. and Kashiwagi, S.: Seroepidemiology of hepatitis $\mathrm{C}$ virus infection in hemodialysis patients and the general population in Fukuoka and Okinawa, Japan. J. Gastroenterol. 29: 276-281, 1994.

18) Miyajima, I., Sata, M., Murashima, S., Suzuki, H., Kondo, S., Ito, Y., Kawano, H. and Tanikawa, K.: Prevalence of hepatitis C antibodies in health care personnel. Kansenshogaku Zasshi 71:103-107 (in Japanese with English abstract), 1997.

19) Scully, C., Griffiths, M. J., Levers, H., Blake, C. and Chartres, L.: The control of cross-infection in UK clinical dentistry in the 1990's: immunisation against hepatitis B. Br. Dent. J. 174: 29-31, 1993.

20) Nagao, Y., Sata, M., Tanikawa, K., Itoh, K. and Kameyama, T.: High prevalence of hepatitis C virus antibody and RNA in patients with oral cancer. J. Oral Pathol. Med. 24: 354-360, 1995.

21) Takata, Y., Kurokawa, H., Tateishi, A., Fujikawa, M., Wakisaka, M., Matsumura, K., Kajiyama, M. and Fukuda, J.: Evaluation of HCV infection by HCV-RNA and HCV antibody in patients hospitalized in oral surgery division. J. Kyushu Dent. Soc. 52: 387-391, 1998.

22) Fenlon, M. R. and McCartan, B. E.: Medical status of patients attending a primary care dental practice in Ireland. J. Ir. Dent. Assoc. 37: 75-77, 1991. 


\section{歯科入院患者における \\ 肝炎ウイルス感染と肝臓病}

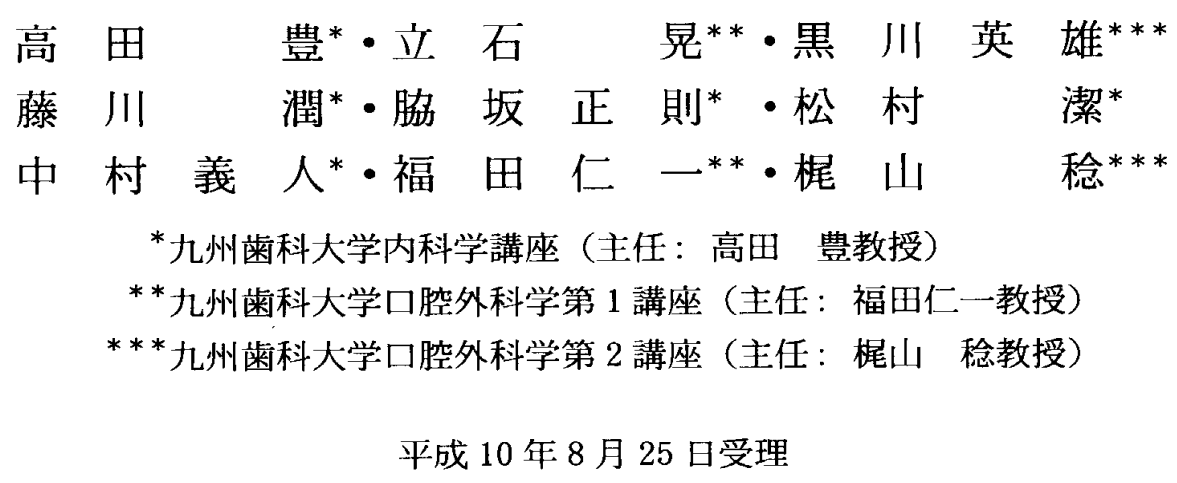

㐘科入院患者を対象に, 朋炎ウイルス感染者の頻度及 び, 肝臓病の病歴とウイルス感染·血液生化学值との関 連を検討した. 1994 年 1 月から 1995 年 12 月までに九州 菌科大学口腔外科に入院した 1239 名から肝臟病の病歴 聴取, 血液生化学·血小板数· $\mathrm{HBs}$ 抗原 $\cdot \mathrm{HCV}$ 抗体の測 定を行った。 HBs 抗原陽性率は $1.6 \%, \mathrm{HCV}$ 抗体陽性 率は $6.1 \%$ あっった。 $7.8 \%$ の患者が肝臟病の病歴を 持っていた．肝疾患の病歴を有する者は病歷がない者に 比し，明らかに HBs 抗原（11.6\%対 $0.66 \%$ ) と $\mathrm{HCV}$ 抗体 $(51.2 \%$ 対 $1.79 \%)$ の陽性率が高かった。 また， 肝臓病病歴陽性者は病歴陰性者に比べ有意に血清 GOT,
GPT, 血糖が高值で, 逆に血小板数は少なかった。また, HBs 抗原陽性者は陰性者よりも血小板数が少なかった。 $\mathrm{HCV}$ 抗体陽性者は陰性者に比し, 血清 GOT, GPT, 血 糖が高值で血小板数は低值であった。歯科疾患別では HBs 抗原が良性腫瘍患者に, HCV 抗体が悪性腫瘍患者 に高頻度に陽性である傾向にあったが双方とも有意では なかった，以上の結果から，歯科入院患者は一般住民よ りも HBs 抗原之 HCV 抗体の陽性率が高い可能性が示 唆された. 肝蔵病の病歴を有している患者の菌科治療時 には肝炎ウイルス院内感染予防のための十分な対策が必 要之考えられた。 